DOI https://doi.org/10.18551/rjoas.2021-01.14

\title{
SUITABILITY AREA ANALYSIS FOR THE DEVELOPMENT OF PEARL OYSTERS (PINCTADA MAXIMA) CULTURE USING GEOSPATIAL APPROACHES
}

\author{
Andalus F.* \\ Postgraduate Program, Faculty of Fisheries and Marine Science, \\ University of Brawijaya, Indonesia \\ Sambah A.B. ${ }^{*}$, Guntur \\ Department of Fisheries and Marine Resources Utilization, Faculty of Fisheries and \\ Marine Science, University of Brawijaya, Indonesia \\ *E-mail: absambah@ub.ac.id
}

\begin{abstract}
One of the growing culture businesses in Indonesia is the culture of pearl of the Pintcada maxima type. To maximize marine culture activities, it is necessary to carry out studies related to land suitability analysis based on the types of organisms to be cultivated. This research was carried out in the end of March to April at Gerokgak waters, Buleleng, Bali Indonesia. The research applied survey method to analyze and map the suitability area for Pintcada maxima culture. The criteria observed in this study included ecological criteria consisting of salinity, temperature, dissolved oxygen, $\mathrm{pH}$, brightness, water depth, type of substrate and chlorophyll-a, as well as the limiting factor which consists of conservation area, tourist areas and fishing ground. The research stages include the data collection stage from ecological and limiting factors, then the paired matrix comparison of each parameter were carried out to construct criteria's weight using AHP. The results obtained three categories of suitability classes for the culture area with the suitability class category being very suitable, quite suitable, and not suitable. A suitable location was in the waters with a rocky substrate with a depth of $15 \mathrm{~m}$. This location was identified along the coast, especially on the west side of Gerokgak waters with the recommended culture area was 0-1 nautical miles from the coastline, with a depth of between $15-20 \mathrm{~m}$. The use of temporal-based data was recommended for the future work.
\end{abstract}

\section{KEY WORDS}

Pearls oyster, aquaculture, suitability area, geospatial analysis.

Pearls oyster are one of the important export commodities for Indonesia with a potential economic value of 120 million US \$ per year (Dahuri, 2000). These products are exported to 9 countries, the largest being Hong Kong, Australia, Japan and China. These exported pearls consist of $68 \%$ pearls exploited from nature and $32 \%$ cultured pearls. There are around 65 pearl companies, most of which are scattered in the waters of eastern Indonesia. The supply of pearl oysters originally came from fishing, but nowadays, along with the increasing demand, pearl oyster farming provides a very useful alternative (Winanto, 2004).

The exploitation of the pearl oysters which so far is still dependent on catches in nature and has an impact on the decline of the parent stock of the oysters in various locations. The public's knowledge about oysters aquacultures still poor, which causes the community to only participate in the pearl oyster farming as ordinary employees. So that it causes gaps which in turn will lead to conflict? Pearl culture development efforts at the community level as an effort to empower the community through business segmentation. In addition to increasing the cultivator's income, it is also to straighten the notion that culture cannot be done by the community. Cultivators can do business from spats up to $4 \mathrm{~cm}$ or $5 \mathrm{~cm}$ in size to be sold to companies later. This effort can also help the company due to in reality the company still lacks spat. 
The success of pearl culture is very much determined by the suitability of the location. A suitable location is defined as an area that has physical characteristics that support life or is in accordance with the pearl habitat. According to Arnold et. al (2003), suitable locations for pearl oyster aquaculture must be protected from large waves, have weak currents and are far from polluting sources. The substrate conditions also affect the success of this culture business (Hossain et. al, 2007). Sandy or craggy substrates and clear water are more suitable for culture locations when compared to muddy and cloudy substrates.

One of the technologies that can be used in survey and research activities on marine and fisheries resource potential mapping is GIS (Geographic Information System) technology or can be defined as geospatial analysis. GIS is an organized collection of hardware, software, geographic data, supporting data and personnel that is designed efficiently to obtain, store, manipulate, analyze and display all forms of geographically referenced information (Prahasta, 2001).

Cell Based Modeling method in the term of GIS is more often used in modeling water conditions, this technique uses raster data that works based on cells or pixels (ESRI, 2002). According to Pasek (2007), the raster data source used in the Cell Based Modeling approach can be derived from satellite images. Furthermore, Molenaar (1998) in Pasek (2007) states that one of the advantages of this method is in terms of the ease and speed of performing overlay operations, making distances and parameter welding. Another advantage of this method is the simple raster data structure that makes modeling and analysis easier, and compatible with satellite image data because it has high variability in displaying water conditions (Pasek, 2007).

The research tried to analyze the ecological parameter for pearl oysters aquaculture, and to map the suitability area as well as mapping the potential area to be developed as a pearl oyster aquaculture location. The research was done at the Gerokgak waters, Buleleng Regency, Bali, Indonesia.

\section{METHODS OF RESEARCH}

Suitability area mapping for pearl oyster culture using the spatial analysis approach in this study is more focused on the ecological aspects. This study is based on a model developed by Radiarta et al. (2008; 2011) by considering two categories, namely supporting factors and limiting factors. Supporting factors consist of two criteria, namely ecological criteria which include salinity, temperature, dissolved oxygen, $\mathrm{pH}$, brightness, water depth, type of substrate and chlorophyll -a. While limiting factors are specific conditions in the field that can limit culture activities or locations that cannot be used for pearl oyster culture.

The limiting factors in this study are shipping lanes, conservation areas, and fishing areas. Furthermore, the supporting factor is called the level-1 criterion and its parameters are referred to as the level-2 criterion. Operationally this research is divided into three stages of research. The first stage is the stage of collecting data from each of the compiler criteria for area suitability analysis for pearl oyster culture. Data measurement is done through direct measurement or data acquisition in the field. Measurement of data from ecological criteria is carried out directly in situ in Gerokgok waters, Buleleng Regency. The second stage is the paired matrix calculation and the determination of the weight of each criterion using the Analytical Hierarchy Process (AHP) method as a decision support system.

According to Saaty (1980), the steps to be used to solve problems using AHP include the stages of problem decomposition, assessment to compare elements, compilation of matrices and consistency tests, setting priorities for each hierarchy, synthesis of priorities and decision making. AHP method can produce a level of consistency from the weight made by calculating the consistency ratio. A ratio value less than or equal to 0.1 is an acceptable value and shows consistent weighting (Radiarta et al., 2011). In this study, the level of importance of each criterion was compiled based on the results of interviews with experts. The third stage is the mapping stage through the GIS approach. In the mapping process, all data resulting from field measurements from each criterion are converted into raster data through interpolation techniques. Furthermore, the calculation results of the matrix and 
weights are inputted and digitized in order to obtain a thematic map of the ecological criteria and limiting factors for further merging process using the overlay technique.

Ecological criteria include physical and chemical parameters of the waters. Measurement of the physical and chemical parameters of the waters is carried out in situ. The parameters observed included salinity, temperature, $\mathrm{pH}$, dissolved oxygen (DO), brightness, water depth, type of substrate and land protection. The measurement of the physical and chemical parameters of the waters is carried out at 09.00-16.00 WITA by using a boat as a means of transportation. Salinity data was collected using a refractometer, temperature data was collected using a thermometer, $\mathrm{pH}$ data using a $\mathrm{pH}$ meter, brightness using a secchi disc, dissolved oxygen data using a DO meter, and depth data was collected using a predetermined rope at the coordinates determined using GPS. Apart from field data, secondary data in the form of base maps and water depths were also collected.

In this research, the base map was obtained from digitizing the habitat distribution map, conservation area map and fishing ground map of traditional fishermen obtained from the Locally Managed Marine Area Network (LMMA). Depth data digitized from the bathymetric map of the north Bali sea obtained from the Center for Research and Development of Marine and Coastal Resources, P3SDLP, Ministry of Marine Affairs and Fisheries.

The criteria for area suitability for pearl (Pintcada maxima) culture are determined according to the quality of marine water parameters. The determination of the criteria for area suitability for pearl culture was based on the modification from DKP (2002) and the results of previous studies, as described in Table 1, while the overall data analysis as described in the research flow chart in Figure 1.

Table 1 - Parameters and its standard criteria values for pearl culture

\begin{tabular}{|c|c|c|c|c|c|c|}
\hline No. & Parameters & Unit & Range & $\begin{array}{l}\text { Score } \\
(\mathrm{S})\end{array}$ & $\begin{array}{c}\text { Weight (\%) } \\
\text { (B) }\end{array}$ & $\begin{array}{l}\text { Value } \\
(\mathrm{S} \times \mathrm{B})\end{array}$ \\
\hline \multirow[t]{3}{*}{1} & Phytoplankton & $\mathrm{Sel} / \mathrm{L}$ & $>15000 \&<5 \times 10^{5}$ & 5 & \multirow{3}{*}{30} & 150 \\
\hline & & & $2000-15000 \& 5 \times 10^{5}-10^{6}$ & 3 & & 90 \\
\hline & & & $<2000 \&>10^{6}$ & 1 & & 30 \\
\hline \multirow[t]{3}{*}{2} & Current & $\mathrm{cm} / \mathrm{dt}$ & $15-25$ & 5 & \multirow{3}{*}{15} & 75 \\
\hline & & & $10-15 \& 25-30$ & 3 & & 45 \\
\hline & & & $<10 \&>30$ & 1 & & 15 \\
\hline \multirow[t]{3}{*}{3} & Water depth & Meter & $10-20$ & 5 & \multirow{3}{*}{10} & 50 \\
\hline & & & $21-30$ & 3 & & 30 \\
\hline & & & $<10 \&>30$ & 1 & & 10 \\
\hline \multirow[t]{3}{*}{4} & Dissolved oxygen & $\mathrm{mg} / \mathrm{l}$ & $>6$ & 5 & \multirow{3}{*}{5} & 25 \\
\hline & & & $4-6$ & 3 & & 15 \\
\hline & & & $<4$ & 1 & & 5 \\
\hline \multirow[t]{3}{*}{5} & Temperature & ${ }^{\circ} \mathrm{C}$ & $28-30$ & 5 & \multirow{3}{*}{5} & 25 \\
\hline & & & $31-32$ & 3 & & 15 \\
\hline & & & $<28 \&>32$ & 1 & & 5 \\
\hline \multirow[t]{3}{*}{6} & Salinity & ppt & 32 & 5 & \multirow{3}{*}{5} & 25 \\
\hline & & & $33-35$ & 3 & & 15 \\
\hline & & & $<32 \&>35$ & 1 & & 5 \\
\hline \multirow[t]{3}{*}{7} & Water brightness & Meter & $4.5-6.5$ & 5 & \multirow{3}{*}{15} & 75 \\
\hline & & & $3.5-4.4 \& 6.6-7.7$ & 3 & & 45 \\
\hline & & & $<3.5 \&>7.7$ & 1 & & 15 \\
\hline \multirow[t]{3}{*}{8} & Substrate & & Compose & 5 & \multirow{3}{*}{10} & 50 \\
\hline & & & Sandy & 3 & & 30 \\
\hline & & & Muddy sand & 1 & & 10 \\
\hline
\end{tabular}

Geospatial Analysis includes any of the formal techniques which studies entities using their topological, geometric, or geographic properties. After the database and spatial data have been formed, the next step is to perform an overlay analysis that combines information from several maps to produce new information using Spatial Multi Criteria Analysis (Malczewski, 1999). Overlay is a spatial analysis capability that can be carried out effectively in GIS. The result of the spatial analysis is a map for the suitability of the pearl oyster culture area. Illustration of overlapping analysis to obtain a map of land suitability for pearl oyster culture as described in Figure 2.

Temperature measurements were carried out directly in Gerokgak waters and obtained temperature data ranging from $28{ }^{\circ} \mathrm{C}$ to $31^{\circ} \mathrm{C}$. Based on the map, it shows that most of the 
Gerokgak waters have temperatures ranging from $25^{\circ} \mathrm{C}$ to $30{ }^{\circ} \mathrm{C}$. According to Wiradisastra (2004), a good temperature range for pearl oyster culture is between $26-30{ }^{\circ} \mathrm{C}$. The temperature value in deep water areas with strong currents has a relatively lower temperature value, while areas with shallow waters with low flow movements have a higher temperature value. In addition, areas close to the coast and river estuaries also have higher temperature values. This condition is caused by the movement of fresh water masses from rivers that easily enter nearshore waters.

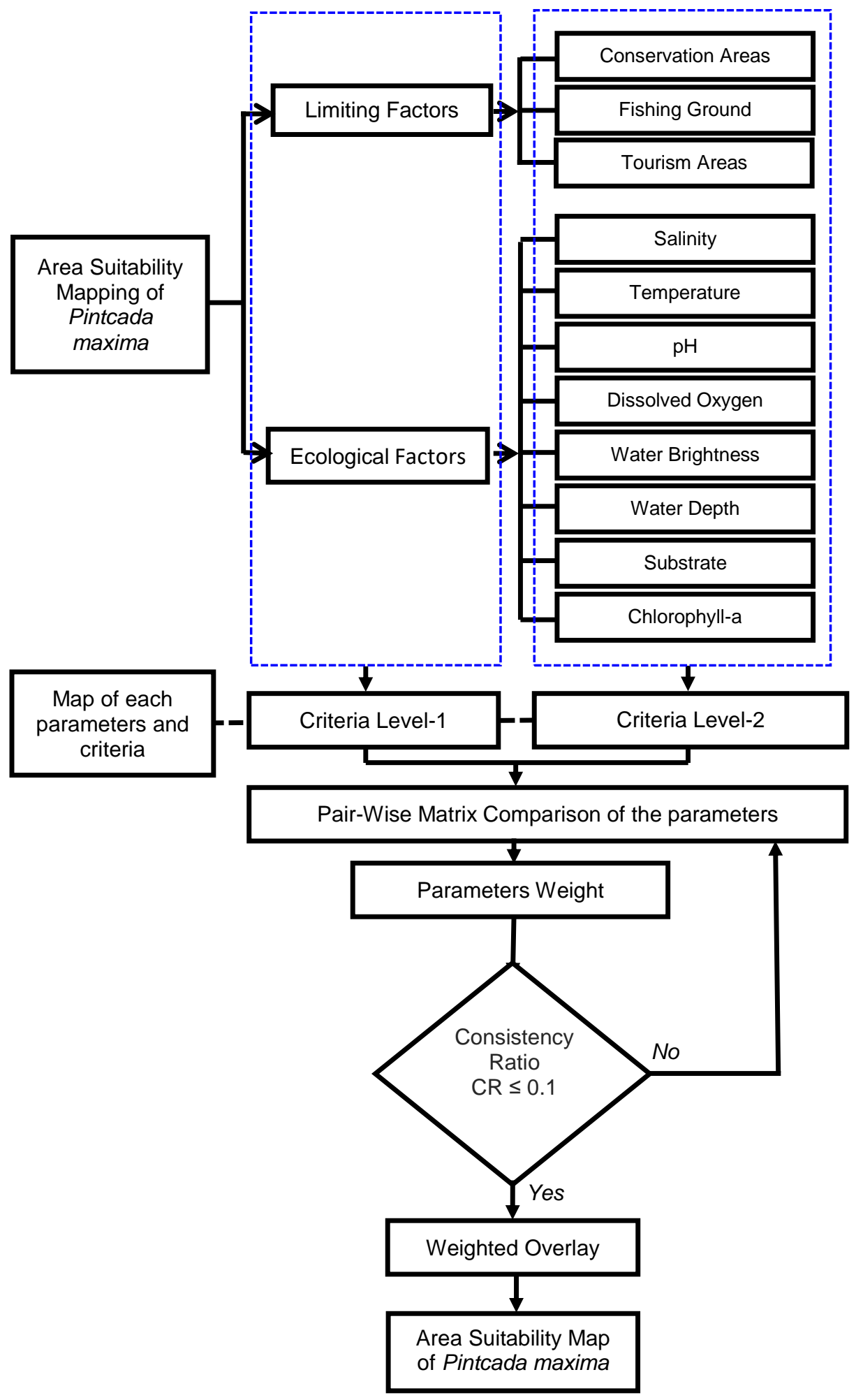

Figure 1 - Flow diagram of research method 


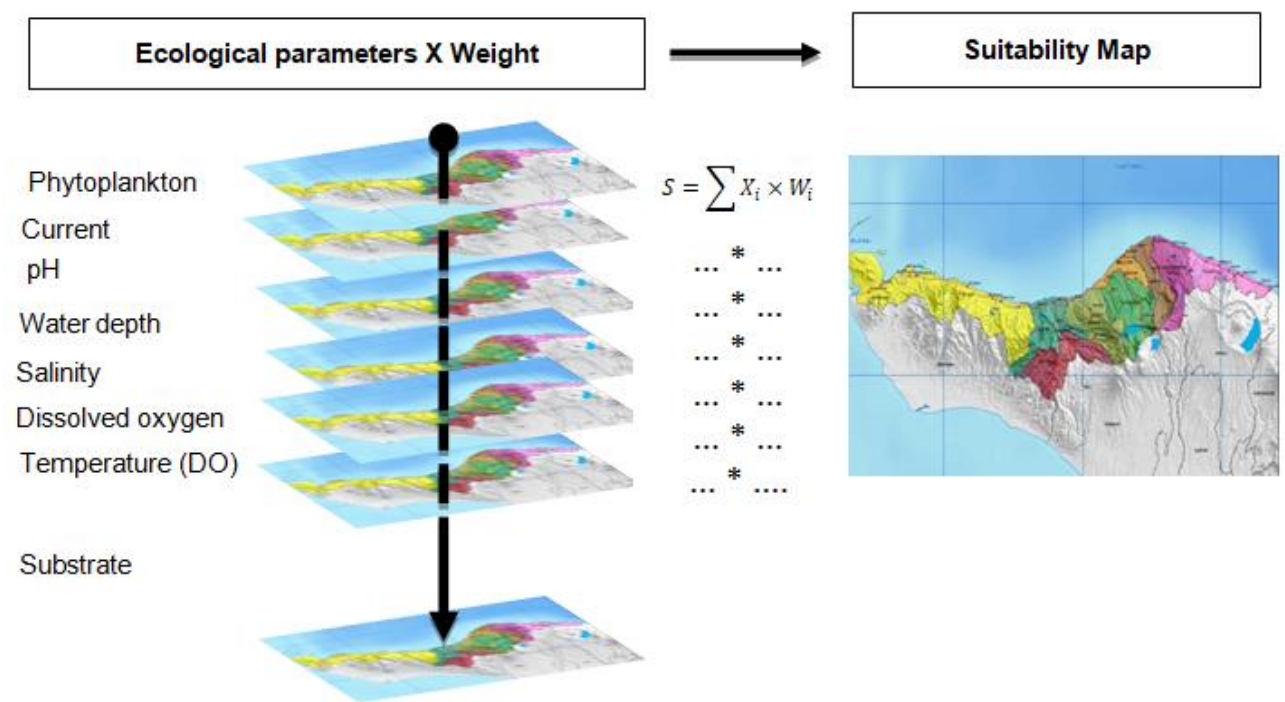

Figure 2 - Weighted overlay illustration applied in this study

\section{RESULTS AND DISCUSSION}

Moreover, dissolved oxygen (DO) can also be used as an indicator of water pollution. If the dissolved oxygen level is very low from the lower limit required by aquatic biota, the waters are already polluted. Waters used for aquaculture should have DO levels of $5 \mathrm{mg} / \mathrm{l}$. DO levels of less than $4 \mathrm{mg} / \mathrm{l}$ have detrimental effects on all aquatic biota (Effendi, 2003). The measurement of DO in Gerokgak waters ranged from 4.7 to $6.97 \mathrm{mg} / \mathrm{l}$. Most of the Gerokgak waters have DO content of less than $6.8 \mathrm{mg} / \mathrm{l}$. the DO value of each area around Gerokgak waters has a not too much difference, although the DO values at several stations show a small difference. This can be caused by differences in currents in water areas. Flow velocity plays an important role in waters, among others, for mixing the water mass, transporting nutrients, and transporting oxygen (Akib et al., 2015). Most of the Gerokgak waters showed a decent DO value for pearl oyster culture. Pearl oysters (Pinctada maxima) required oxygen for respiration. Respiration supports the process of pearl metabolism so that the DO content in the waters is essential for the continuity of its growth process. One of the factors that need to be considered in the maintenance of pearl is DO ranging from $4.9-6$ $\mathrm{mg} / \mathrm{l}$ (Sujoko, 2010). Pearl oysters (Pinctada maxima) can live and develop well in cultivated areas with DO content ranging from 5.2 to $6.6 \mathrm{mg} / \mathrm{l}$ (Imai, 1971). In this condition, it is known that the productivity level of pearl oyster is still good.

Based on the field measurements, it showed that the $\mathrm{pH}$ value did not vary greatly, ranging from 6.3 to 6.5. The degree of acidity $(\mathrm{pH})$ has a very big influence on aquatic organisms so that it is used as a guide to declare the good and bad of waters which still depends on other factors. The $\mathrm{pH}$ value in Gerokgak waters can be categorized into very weak acidic $\mathrm{pH}$. Acidic waters tend to cause death in aquatic organisms, this is due to low oxygen concentrations so that respiratory activity is high and appetite is reduced (Kordi, 2010 ) in pearl oyster culture, the optimum pH range is 7.8 - 8.6 (Pandey et. al., 2006).

The measurement results of the brightness parameters ranged from 6 meters to 10.8 meters. Brightness is a measure of the transparency of the waters. The brightness value is influenced by weather conditions, measurement time, turbidity and suspended solids (Effendi, 2003). The brighter the waters, the deeper the sunlight penetrates the waters and vice versa. For the purposes of pearl culture, a location with a brightness between 4.5 - 6.5 meters should be chosen. usually cultivated shellfish are placed below average depth or brightness (Sutaman, 1993).

In addition, the results of salinity measurements around Gerokgak waters obtained a range of salinity values of $32 \mathrm{ppt}-36$ ppt. Based on the data obtained, it shows that the differences not too significant at each observation station. The highest salinity values were in 
areas close to the coast and land which has a fairly low depth. Pearl oysters are very tolerant of changes in salinity, because these animals include Euryhaline which can live in a wide salinity range and can survive in salinity between $24-50 \%$, but at salinity below $14 \%$ or above $55 \%$ can cause pearl death. To be able to grow and develop properly, pearl need waters with a salinity range between 32 - $35 \%$ (Sutaman, 1993). The salinity level in Gerokgak waters with a range of 32 - 36 ppt was optimal for oyster survival and pearl oyster culture productivity. The effect of salinity levels on pearl oyster culture is related to the quality of the pearls that will be formed in the pearl shell body.

The measurement of the depth parameters obtained various results; the water depth from the lowest was 1 meter to a depth of 24 meters. At this depth, pearl oyster growth will be better. The depth of the waters at the culture location affects the quality of the pearls produced. According to Sutaman (1993), the suitable depth for pearl oyster culture is between 15-20 meters. Current also play as important parameter in the marine aquaculture. Currents are the process of moving the mass of sea water towards equilibrium which can cause continuous vertical and horizontal displacement of water (Wyrtki 1961 in Andre, 2007). The existence of currents in the sea is caused by differences in sea water mass density, continuous wind blowing above sea level and tides, especially in coastal areas (Satriadi and Widada, 2004 in Kangkan 2006). The measurement results at the research location showed that the current velocity in Gerokgak waters ranges from $1.5-10 \mathrm{~cm} / \mathrm{second}$. Spatial variability of the parameters as described in Figure 3.

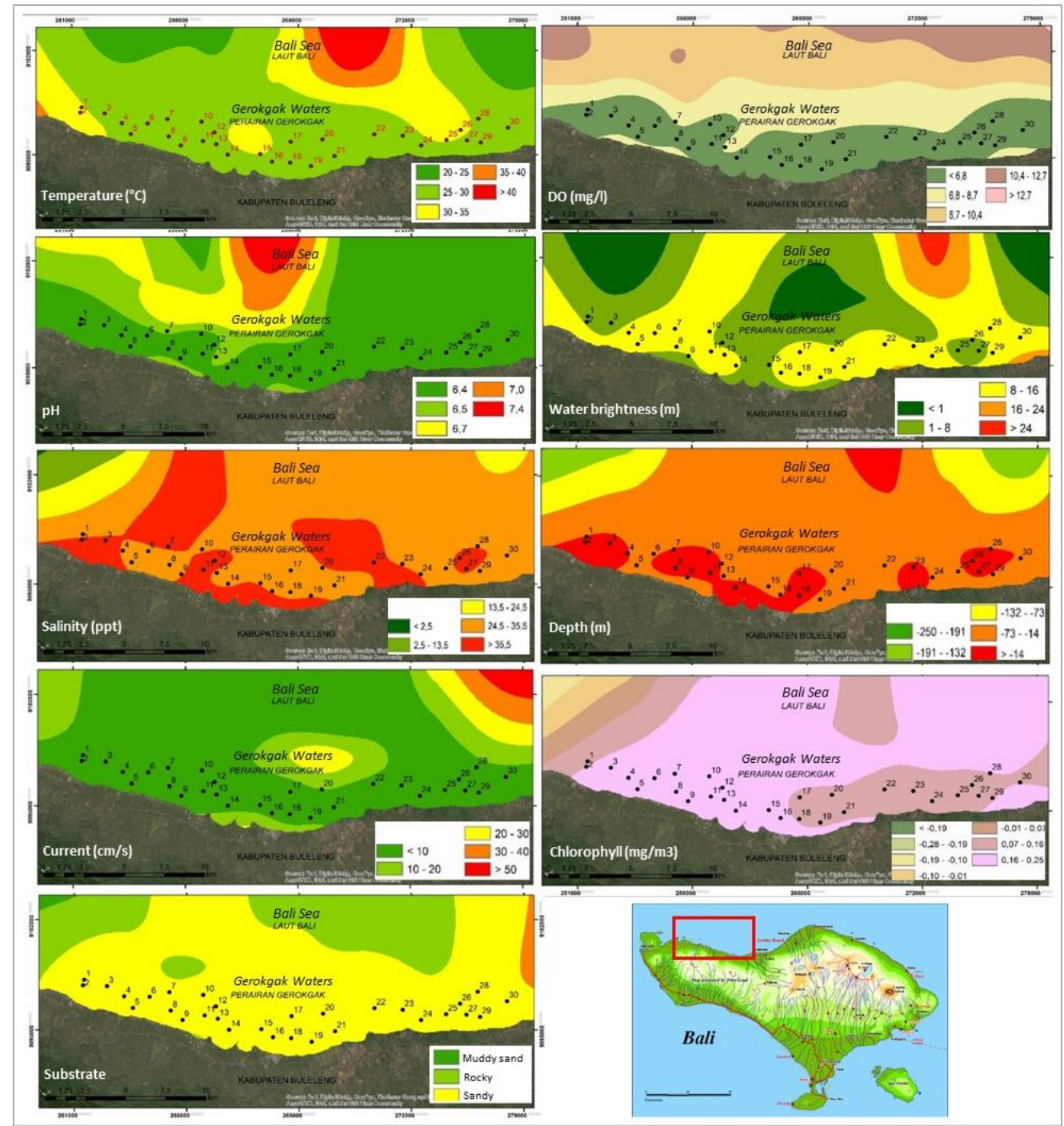

Figure 3 - Spatial variability of the parameters for suitability area mapping applied in the potential mapping of pearl oyster culture 
Pearl oysters, which are classified as filter feeders, only rely on food by absorbing plankton from the surrounding waters, so the availability of natural food plays an important role. Apart from being natural food, phytoplankton has another role, namely to function as a buffer for water quality (Sutaman 1993). According to Basmi (2000), a good density of phytoplankton in a culture location ranges from 15,000 to $5 \times 105$ cells/l. Plankton are pelagic organisms that float or move with the current (Bal and Rao 1984 in Kangkan 2006), consisting of two types, namely phytoplankton and zooplankton. Plankton has an important role in the marine ecosystem, because it is a food ingredient for various types of marine life (Nontji 2005). Measurement of chlorophyll-a in this study was carried out using secondary data in the form of Aqua MODIS images on October 30, 2019. Most of the research areas were known to have chlorophyll values ranging from $0.7-0.25 \mathrm{mg} / \mathrm{m} 3$. Type of pearl oyster (Pinctada sp.) can be found in various countries such as the Philippines, Thailand, Myanmar, Australia and Indonesian waters that like to live in rocky areas or sandy waters with a depth of $20-60 \mathrm{~m}$. Based on the results of field observations, it can be seen that the bottom of Gerokgak waters was sand.

The multi-criteria spatial model is an approach used to determine the suitability area for aquaculture in Gerokgak waters, Buleleng, Bali by considering several criteria. The measurement results of each parameter were then analyzed through the GIS approach to determine the level of suitability. The interpolation results of each parameter were overlaid using a weighted overlay approach, according to the illustration in Figure 4.

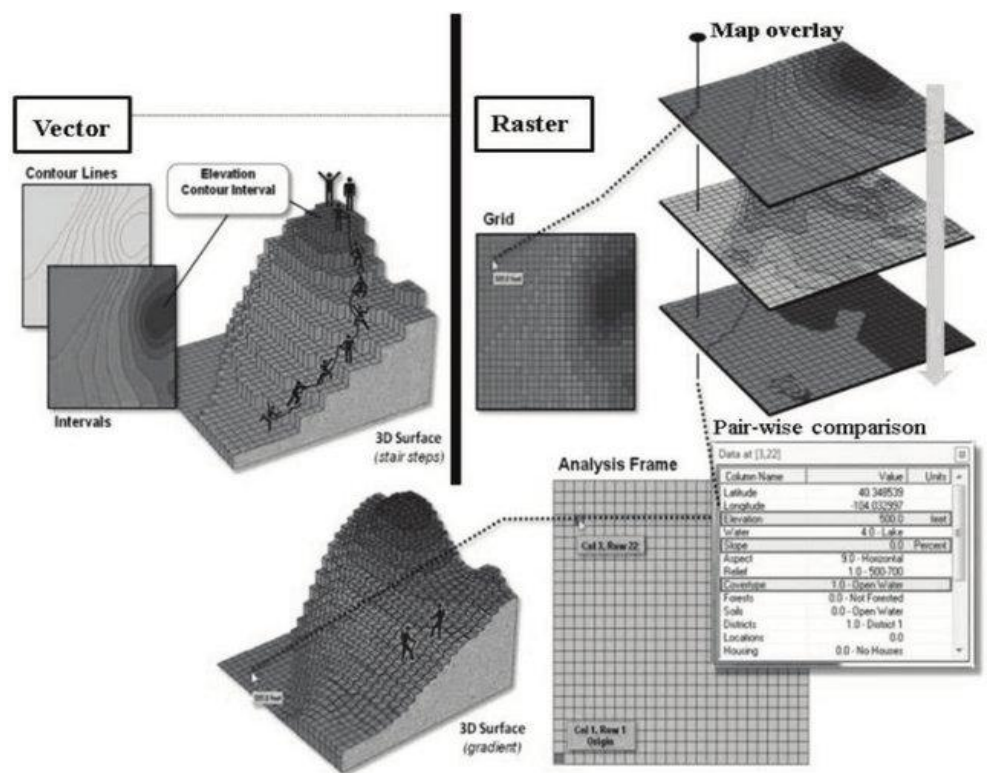

Figure 4 - Weighted overlay process in spatial multi criteria analysis (Sambah and Miura, 2019)

Meanwhile, the mathematical calculation of the overlay used in the data analysis process is as illustrated in the following equation. (Effat and Hegazy, 2013).

$$
S=\sum\left(W_{i} \cdot X_{i}\right)
$$

Where: $\mathrm{S}=$ suitability result, $\mathrm{W}_{\mathrm{j}}=$ weight for each parameter applied, $\mathrm{X}_{\mathrm{ij}}=$ attribute score.

The collected data from the field measurement were interpolated using the IDW interpolation approach to determine the suitability level based on its criteria. (Table-1). The result of the interpolation process was a thematic map of each parameter. To obtain an area suitability map based on ecological criteria, all thematic maps of ecological parameters were overlaid using a weighted overlay approach, which is one of the overlay facilities in the Geographical Information System. The Weighted Overlay tool applies one of the most used approaches for overlay analysis to solve multicriteria problems such as site selection and 
suitability models. In a weighted overlay analysis, each of the general overlay analysis steps are followed (ESRI, 2020). The weighted overlay process required weight calculation for each parameter. To calculate the weight for each parameter, the AHP (Analytical Hierarchy Process) approach is used through the calculation of pair-wise matrix comparison (Saaty, 1980; Sambah \& Miura 2013). The scale of comparison between parameters in determining this weight is based on the 9 Saaty scale. The assumption used is that each parameter has a different role and influence in determining the suitability area for pearl oyster culture. The results of this calculation which shows the weight value of each parameter are as described in Table 1. The calculation of consistency ratio (CR) from AHP application in this study was $4.8 \%$. Suitability area for pearl oyster culture as a result of this study as described in Figure 5.

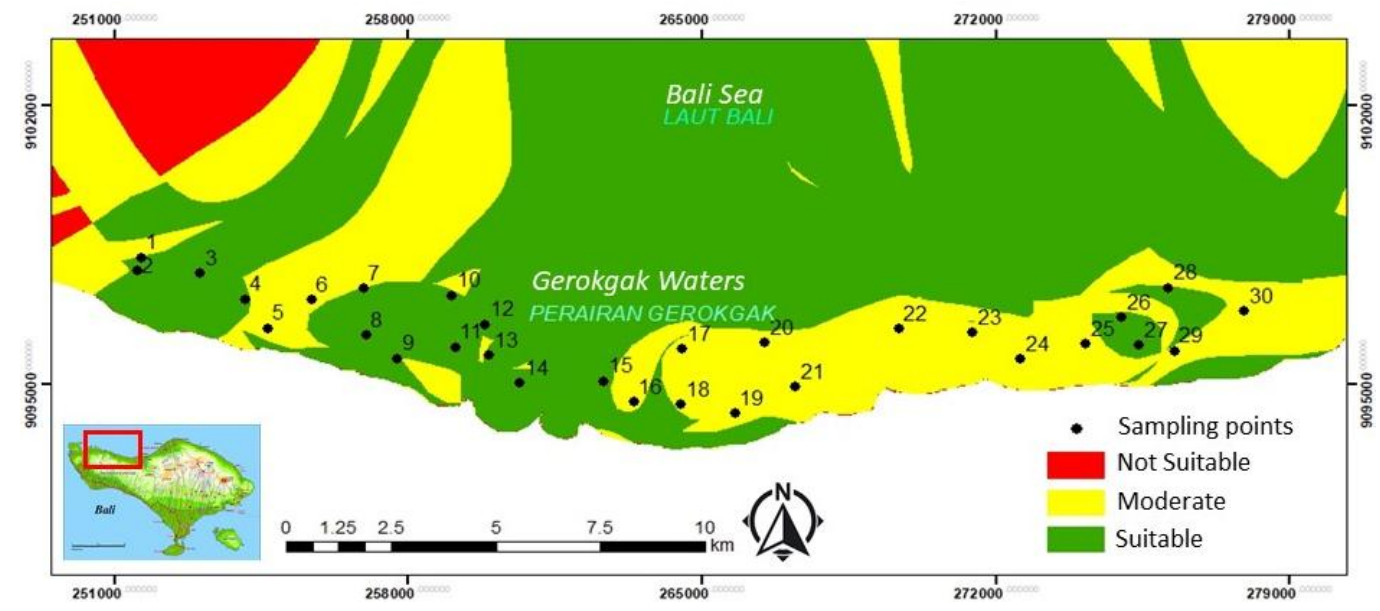

Figure 5 - Suitability area map for pearl oyster culture

Based on the results of suitability area mapping for pearl oyster culture in Gerokgak waters, it described three categories of suitability classes; suitable, moderate, and not suitable. A suitable area was spread in waters with a rocky substrate with a depth of $15 \mathrm{~m}$. A suitable location was located in most of the Gerokgak water area with a depth of $15-20 \mathrm{~m}$, closed to the coastal area until 3-4 mile to the Bali Sea. The recommended area for pearl oyster culture based on the study was the area along coastal from the latitude of 251000 UTM Easting until 265000 UTM Easting and 9090000 UTM Northing until 9100000 UTM Northing. Meanwhile, the not suitable location was found in the west part of study area and far from the coastline with a depth of more than $30 \mathrm{~m}$.

The success of pearl oyster culture is strongly influenced by the food presence in which phytoplankton is the main food for Pinctada sp. The concentration of plankton also has a close correlation to the development of pearl oyster gametes (Pouvreau \& Prasil 2001; Fukumori et al 2008; Fournier et al., 2012). Moreover, water flow is also an important factor for disributing food for the growth of the pearl oyster, the higher water flow is the higher the food supply is also abundant (Lacoste et al., 2014). Some of the standard environmental parameters to be considered in the pearl oyster culture are temperature, salinity, hydrogenion $(\mathrm{pH})$ concentration and nutrient salts. Temperature is essential in many respects, particularly in regulating the metabolic rate of the animal. It also controlling the reproductive cycle as in sub-tropical and temperate waters which influences the quality of pearls (Athavale et al., 2020)

A number of environmental factors plays a predominant role in determining the color and luster of the pearl nacre. Water depth also one of the most important factors, as quality pearls tend to be produced in waters below $10 \mathrm{~m}$. The pearl culture grounds also play a significant role in determining pearl quality, and repeated culture on the same ground has been shown to affect the quality of pearls. Organic substances discharged by the pearl oysters and fouling organisms are deposited on the sea bottom and their build-up eventually affects the chemical and physical state of the water. The growth, size and colour of pearl is 
also depend on the physiological state of the pearl oyster and the condition of the culture ground have bearing on oyster. This depends principally on differences in chemical composition of the seawater, as well as the kind and number of plankton in the area where the pearl oysters are reared. The chief source of conchiolin is the nitrogenous substances of the plankton, which influences the colour of pearls (Chellam et al., 1991).

\section{CONCLUSION}

The combination approaches of AHP and GIS through multi-criteria analysis with the process of weighted overlay saw good perform in the integrated analysis between the criteria to map the suitability area for pearl oyster culture. The results described three categories of suitability classes in the Gerokgak waters of Buleleng, Bali Indonesia for the pearl oyster culture. A very suitable and suitable location was found in waters with a rocky substrate with a depth of $15 \mathrm{~m}$. This location was identified along the coast line until one nautical mile to the north area, with a depth of between $15-20 \mathrm{~m}$. The use of temporal-based data is recommended for the future work with at least the in-situ measurement covered one-year data collection. The use of satellite data also can be use in order to prepare the oceanographic dataset when the coverage area larger than the current study.

\section{REFERENCES}

1. Andre, R. B. 2007. Aplikasi Penginderaan Jauh and Sistem Informasi Geografis Dalam Menentukan Kesesuaian Lahan Budidaya Rumput Laut (Gracilaria sp.) Di Wilayah Babelan, Jawa Barat. Bachelor thesis. IPB, Bogor.

2. Akib, A., M. Litaay, A. Ambeng, \& M. Asnady. 2015. Kelayakan Kualitas Air Untuk Kawasan Budidaya Eucheuma Cottoni Berdasarkan Aspek Fisika, Kimia and Biologi di Kabupaten Kepulauan Selayar. Jurnal Pesisir and Laut Tropis, 1(1).

3. Athavale S.A, M.S. Hambarde, \& S.S. Parab. 2020. Water Quality and Chemical Analysis of Marine Cultured Pearl and its Oyster Shell. International Research Journal of Engineering and Technology (IRJET), 07(03): 4989-4994.

4. Arnold, S.W., White, M.W. \& Berrigan, M.E. 2003. Hard Clam (Mercenaria spp) quaculture in Florida,USA: Geograpgic Information System Application to Lease Site Selection. Journal of Aquacultural Engineering, 23: 203-231.

5. Basmi, H.J., 2000. Planktonologi: Plankton Sebagai Indikator Kualitas Perairan. Fakultas Perikanan and IImu Kelautan, Bogor: IPB.

6. Effat, H. A., \& M. N. Hegazy. 2013. A Multidisciplinary Approach to Mapping Potential Urban Development Zones in Sinai Peninsula, Egypt Using Remote Sensing and GIS. Journal of Geographic Information System, 5(6) DOI:10.4236/jgis.2013.56054)

7. Chellam, A., A.C.C. Victor, S. Dharmaraj, T.S. Velayudhan, K. Satyanaryana Rao, \& P.S.B.R. James. 1991. Pearl Oyster Farming And Pearl Culture. Chapter XIV Improvement of Pearl Quality. Training Manual 8. Central Marine Fisheries Research Institute.

8. Effendi H. 2003. Telaah Kualitas Air Bagi Pengelolaan Sumber Daya and Lingkungan Perairan. Yokyakarta: Penerbit Kanisius, 258 hal.

9. ESRI. 2000. GIS For School and Libraries Version 5. Environmental System Research Institute.

10. ESRI. 2020. How-weighted-overlay-works. Arcgis tutorial. Accessed from https://desktop.arcgis.com/en/arcmap/10.3/tools/spatial-analyst-toolbox/how-weightedoverlay-works.htm

11. Dahuri, R. 2000. Pendayagunaan Sumberdaya Kelautan Untuk Kesejahteraan Rakyat. Jakarta: Lembaga Informasi and Studi Pembangunan Indonesia (LISPI).

12. DKP-Departemen Kelautan and Perikanan Republik Indonesia. 2002. Modul Sosialisasi and Orientasi Penataan Ruang Laut, Pesisir and Pulau-pulau Kecil. Ditjen Pesisir and Pulau-Pulau Kecil. Edisi Tahun 2002. Departemen Kelautan and Perikanan RI. Jakarta. 
13. Fournier J., E. Levesque, S. Pouvreau, M. Le Pennec, \& G. Le Moullac. 2012. Influence of plankton concentration on gametogenesis and spawning of the black lip pearl oyster Pinctada margaritifera in Ahe atoll lagoon (Tuamotu Archipelago, French Polynesia). Marine Pollution Bulletin, 65: 463-470.

14. Hossain, S.H., Chowdhury, S.R \& Rahaman, M.M. 2007. Multi-criteria Evaluation Approach to GIS-based Landsuitability Classification for Tilapia Farming in Bangladesh. Aquaculture International, 15: 425 - 443.

15. Imai, T. 1971. Aquaculture in Shallow Seas. Progress in Shallow Sea Culture. Tokyo: Oxford and IBH Pub., $136-230$.

16. Kordi, M. \& Ghufran K. 2010. Budi Daya Ikan Patin di Kolam Terpal. Yogyakarta: ANDI.

17. Kangkan, A.L. 2006. Studi Penentuan Lokasi Untuk Pengembangan Budidaya Laut Berdasarkan Parameter Fisika, Kimia and Biologi Di Teluk Kupang, Nusa Tenggara Timur. Master thesis. UNDIP, Semarang.

18. Lacoste E., G.L. Moullac, P. Levy, Y. Gueguen, \& N. Gaertner-Mazouni. 2014. Biofouling development and its effect on growth and reproduction of the farmed pearl oyster Pinctada margaritifera. Aquaculture, 434: 18-26.

19. Nontji, A. 2005. Laut Nusantara. Edisi revisi. Penerbit Djambatan, Jakarta.

20. Malczewski. J. 1999. GIS and Multicriteria Decision Analysis. John Wiley \& Sons. New York. $392 \mathrm{pp}$.

21. Pandey A, P. Trivedi, B. Kumar, L.M.S Palni. 2006. Characterization of a phosphate solubilizing and antagonistic strain of Pseudomonas putida (B0) isolated from a subalpine location in the Indian Central Himalaya. Curr Microbiol, 53(2): 102-107.

22. Pasek, I.M.R.S. 2007. Penentuan Zona Potensial Budidaya Mutiara Dengan Cell Based Modelling di Perairan Sekotong Lombok Barat. Bachelor thesis. Jurusan Ilmu and Teknologi Kelautan. IPB. Bogor. xii + 89p.

23. Pouvreau S., \& V. Prasil. 2001 Growth of the black-lip pearl oyster, Pinctada margaritifera, at nine culture sites of French Polynesia: synthesis of several sampling designs conducted between 1994 and 1999. Aquat Living Resour, 14: 155-163.

24. Prahasta. 2001. Konsep - Konsep Dasar Sistem Informasi Geografi. Informatika. Bandung.

25. Radiarta I.N., Sei-Ichi Saitoh, \& Miyazono A. 2008. GIS-Based Multi-Criteria Evaluation Models for Identifying Suitable Sites for Japanese Scallop (Mizuhopecten yessoensis) Aquaculture In Funca Bay, Southwestern Hokkaido, Japan.

26. Radiarta I.N., Saputra A., \& Ardi I. 2011. Analisis Spasial Kelayakan Lahan Budidaya Kerang Hijau (Perna viridis) Berdasarkan Kondisi Lingkungan di Kabupaten Cirebon, Jawa Barat. Jurnal Riset Akuakultur, 6(2): 341-352.

27. Saaty T. L. 1980. Decision Making with The Analitical Hierarchy Process. International Journal Services Sciences. 1(1).

28. Sambah, A. B, \& F. Miura. 2019. Geo Spatial Analysis for Tsunami Risk Mapping. In book: Advanced Remote Sensing Technology for Synthetic Aperture Radar Applications, Tsunami Disasters, and Infrastructure. London: InTechopen Publisher.

29. Sujoko, A. 2010. Membenihkan Kerang Mutiara. Yogyakarta: Insania.

30. Sutaman, 1993. Tiram Mutiara Teknik Budidaya and Proses Pembuatan Mutiara. Yogyakarta: Kanisus, 93.

31. Winanto, T. 2004. Memproduksi Benih Tiram Mutiara. Depok: Penebar Swadaya.

32. Wiradisastra, U.S. 2004. Laporan Akhir - Analisis Tingkat Kesesuaian Marine Culture Wilayah ALKI II. Buku I (Teknis - analisis). Bogor: Lembaga Penelitian and Pemberdayaan Masyarakat, IPB. 